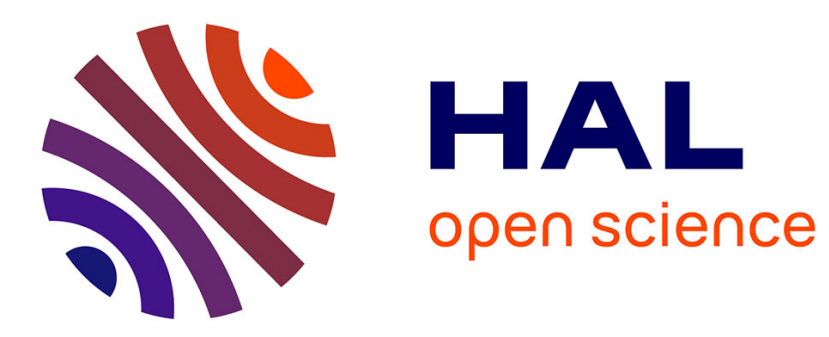

\title{
On the laser snow effect
}

R. Omnès

\section{- To cite this version:}

R. Omnès. On the laser snow effect. Journal de Physique Lettres, 1980, 41 (3), pp.63-64. 10.1051/jphyslet:0198000410306300 . jpa-00231722

\section{HAL Id: jpa-00231722 https://hal.science/jpa-00231722}

Submitted on 1 Jan 1980

HAL is a multi-disciplinary open access archive for the deposit and dissemination of scientific research documents, whether they are published or not. The documents may come from teaching and research institutions in France or abroad, or from public or private research centers.
L'archive ouverte pluridisciplinaire HAL, est destinée au dépôt et à la diffusion de documents scientifiques de niveau recherche, publiés ou non, émanant des établissements d'enseignement et de recherche français ou étrangers, des laboratoires publics ou privés. 


\title{
On the laser snow effect
}

\author{
R. Omnès \\ Laboratoire de Physique Théorique et Hautes Energies, \\ Université de Paris-Sud, 91405 Orsay Cedex, France \\ (Resu le 5 décembre 1979, accepté le 14 décembre 1979)
}

Résumé. - On donne une explication simple de l'effet de neige laser. Cet effet se caractérise par la production de $\mathrm{HCs}$ cristallin dans un mélange gazeux $\mathrm{Cs}-\mathrm{H}_{2}$ sous l'effet d'un laser à argon ionisé.

\begin{abstract}
A simple explanation of the laser snow effect is given. This photochemical effect consists in the production of crystalline $\mathrm{HCs}$ in a Cs- $\mathrm{H}_{2}$ gas mixture under the effect of a ionized argon laser.
\end{abstract}

The purpose of this note is to explain an amusing photochemical effect which has been first reported by Tam, Moe and Happer and is commonly described as the snow laser effect [1]. In this experiment, the radiation from a neon laser passes through a gas mixture made of vapour caesium (at the saturation pressure) and hydrogen. Typical temperatures are from 250 to $400{ }^{\circ} \mathrm{C}$, and a typical $\mathrm{H}_{2}$ pressure is $10^{-1} \mathrm{~atm}$. Some buffer gas such as helium may be added to hydrogen. The caesium doublet lines at 4555 and $4593 \AA$ are broadened enough by collisions under such pressures to overlap with the laser lines at 4545 and $4579 \AA$, so that many caesium atoms are excited from the $6 \mathrm{~s}$ fundamental state to a $7 \mathrm{p}$ state. What is observed is rather spectacular : small crystals (i.e. snow) are produced in the laser beam, scattering the incoming light. Through variation of the buffer composition, it can be ascertained that these crystals are made of $\mathrm{CsH}$.

It turns out that the effect can be explained in an elementary fashion if one retains only the leading terms that behave exponentially with temperature. In fact, there is no point in trying to build a more sophisticated theory since some of the parameters which enter into the exponentials contain too large experimental uncertainties and since the basic cross sections are unknown. Nevertheless, the numbers we shall obtain will be clearcut enough to explain the effect.

We take the system as consisting of two parts : the first part (subsystem 1) consists of everything that lies within the laser beam. The rest of the container (subsystem 2) will be treated as a thermostat at temperature $T$. The extension of thermodynamics to such an out-of-equilibrium system has been treated by Levine and Ben-Shaul [2] but the starting point we shall need is quite simple and easily derived from the second principle of thermodynamics, viz. that the state of minimum Gibbs potential will be produced. We therefore proceed as follows : compute the Gibbs potential $G_{\mathrm{v}}$ of $\mathrm{CsH}$ vapour in the system 1, as if the solid phase were absent, and compare it to the Gibbs potential $G_{\mathrm{c}}$ in the crystalline state. Snow will be produced if $G_{\mathrm{v}}>G_{\mathrm{c}}$.

To compute $G_{\mathrm{v}}$, let us first note that the vapour pressure of caesium is given by the simplified ClausiusClapeyron equation

$$
P_{\mathrm{Cs}}=P_{0} \exp -\frac{\Delta H_{0}}{R T}
$$

where $\Delta H_{0} \simeq 70 \mathrm{~kJ} /$ mole and $P_{\mathrm{Cs}}=1 \mathrm{~atm}$. at $690^{\circ} \mathrm{C}$.

We treat the equilibrium

$$
h v+\mathrm{Cs} \rightleftarrows \mathrm{Cs}^{*}
$$

under the conditions of extreme pumping as a chemical reaction : the ratio between the pressures of excited and non-excited $\mathrm{Cs}$ atoms is given by their statistical weights, i.e. $3 / 4$ for $\mathrm{Cs}^{*}$ (which is in a $l=1$ state, $2 l+1=3$ ) and $1 / 4$ for Cs (in a s-state, $2 l+1=1$ ). When this state of saturation is not realized, the ratio $\mathrm{Cs} / \mathrm{Cs}^{*}$ is an experimental parameter

$$
0 \leqslant \beta \leqslant 3 / 4 \text {. }
$$

The partial pressure of $\mathrm{Cs}^{*}$ is therefore given by

$$
P_{\mathrm{Cs}^{*}}=\cdot \beta P_{0} \exp -\frac{\Delta H_{0}}{R T} .
$$


With no radiation, the partial pressures of Cs, $\mathrm{H}_{2}$ and $\mathrm{CsH}$ are related by the equilibrium equation

$$
\frac{P_{\mathrm{CsH}}^{2}}{P_{\mathrm{Cs}}^{2} P_{\mathrm{H}_{2}}}=K \exp -\frac{\Delta H_{1}}{R T}
$$

with $\log _{10} K=-17.81$ under normal conditions (pressures being measured in atmospheres) [3]. It is known that Eq. (3) can be derived from the Boltzmann equation using the Maxwell distribution for velocities and the cross sections for the reaction

$$
\mathrm{Cs}+\mathrm{H}_{2} \rightarrow \mathrm{CsH}+\mathrm{H}
$$

and its inverse, these two cross sections being related by the principle of detailed balance (time reversal). The same analysis can be applied to the reactions

$\mathrm{Cs}^{*}+\mathrm{H}_{2} \rightarrow \mathrm{CsH}+\mathrm{H} \mathrm{CsH}+\mathrm{CsH} \rightarrow 2 \mathrm{Cs}+\mathrm{H}_{2}$

or whatever mechanism may be. The cross sections for the direct and inverse reactions are not any more simply related, but we shall assume that they are of the same order of magnitude as in the case of unexcited Cs. In fact, we should rather expect that the cross section for $\mathrm{Cs}^{*}+\mathrm{H}_{2}$ is larger than the cross section for $\mathrm{Cs}+\mathrm{H}_{2}$ so that the error we shall make will underestimate the partial pressure of $\mathrm{CsH}$ in the laser beam. We therefore write

$$
\frac{P_{\mathrm{CsH}}^{2}}{P_{\mathrm{Cs}^{*}}^{2} P_{\mathrm{H}_{2}}}=A K \exp \left(-\frac{\Delta H_{1}-2 \varepsilon}{R T}\right)
$$

where $A$ is some unknown factor (of the order of one), $\Delta H_{1}=-86 \mathrm{~kJ} /$ mole being the difference between the $\mathrm{H}-\mathrm{H}$ bond $(436 \mathrm{~kJ} / \mathrm{mole})$ and twice the Cs- $\mathrm{H}$ bond $(175 \mathrm{~kJ} / \mathrm{mole}), \varepsilon$ being the excitation energy of $\mathrm{Cs}(1.76 \mathrm{eV}$ or $170 \mathrm{~kJ} /$ mole). Equation (4) is easily derived from the Arrhenius reaction-rate equation, the only point in the microscopic analysis being to ascertain the order of magnitude of $A$.

The Gibbs potential of vapour $\mathrm{CsH}$ is given, up to small corrections by [4]

$$
G_{\mathrm{v}}=R T \log \frac{P_{\mathrm{CsH}}}{(k T)^{5 / 2}}\left(\frac{2 \pi \hbar^{2}}{m_{\mathrm{CsH}}}\right)^{3 / 2}
$$

where $m_{\mathrm{CsH}}$ is the mass of a CsH molecule.

In order to compute $G_{\mathrm{c}}$ for the solid CsH state, we use the standard enthalpy value $H_{0}=-84 \mathrm{~kJ} / \mathrm{mole}$ and the relations given by the Debye model [4]

$$
G_{\mathrm{c}} \simeq H_{0}+3 R\left(T-T_{0}\right)-3 R T\left[\log \frac{T}{\Theta}+\frac{4}{3}\right]
$$

where $T_{0}$ is the standard temperature and $\Theta$ the Fermi temperature of $\mathrm{CsH}$ which we take approximately as $100 \mathrm{~K}$ (its precise value is of no importance).

Typical numerical values are $T=400{ }^{\circ} \mathrm{C}$, $P_{\mathrm{H}_{2}}=10^{-1}$ atm., $P_{\mathrm{Cs}}=3.6 \times 10^{-2}$ atm., $\beta=3 / 4$ which give $G_{\mathrm{v}}=-33 \mathrm{~kJ} / \mathrm{mole}, G_{\mathrm{c}}=-80 \mathrm{~kJ} / \mathrm{mole}$. With no radiation, one finds $G_{v}$, as given by (3) and (5) equal to $-203 \mathrm{~kJ} / \mathrm{mole}$. It is therefore clear that the solid state is produced when radiation is present, but not in its absence.

I wish to thank S. Feneuille and S. Leach for useful discussions.

\section{References}

[1] Tam, A., Moe, G., Happer, W., Phys. Rev. Lett. 35 (1975) 1630.

[2] Levine, R. D. and Ben-Shaul, A., Chemical and Biological Applications of Lasers, Vol. II, Ed. Bradley Moore (Academic Press), N.Y. 1977.

[3] Handbook of Chemistry and Physics.

[4] See e.g. Landau, L. D. and Lifschitz, E. M., Statistical Physics (Pergamon Press) 1959. 